Journal of Extension Education

Vol. 29 No. 4, 2017

DOI:https: / /doi.org/10.26725/JEE.2017.4.29.5945-5957

\title{
Impact Assessment of Mechanical Transplantation in Cauvery Delta Districts of Tamil Nadu
}

\author{
Ravi Kumar Theodore', N. Venkatesa Palanichamy ${ }^{2}$, V. Ravi ${ }^{3}$,
}

\begin{abstract}
During June 2015, the Government of Tamil Nadu implemented the "Kuruvai Season Special Assistance 2015 for Delta districts" programme to boost rice production. A study was conducted to assess the impact of machine transplanting, which was an important component of this special package. The comparative economics of conventional and machine planting revealed that yield increased by nearly 40.00 per cent; cost of cultivation decreased by 21.00 per cent; cost of production reduced by 43.00 per cent; and net returns increased by more than four times (448.00\%), over the manually planted fields. Farmers' feedback on machine planting was very optimistic with all the beneficiaries expressing that they had opted for machine planting to overcome labour scarcity and to increase yields.
\end{abstract}

Keywords : Impact assessment; Machine transplanting; Rice; Cauvery delta zone; Tamil Nadu.

\section{INTRODUCTION}

Tamil Nadu is one of the leading rice growing states in India, cultivating rice since time immemorial. During 2013-14, the total area under rice was $17,25,730$ ha, with production of $71,15,195$ tonnes, and productivity of 4,123 $\mathrm{kg}$ per ha (Source: Department of Economics and Statistics, Chennai-600 006).

The Cauvery Delta Zone (CDZ) in Tamil Nadu comprising six districts viz., Thanjavur, Tiruvarur, Nagapattinam,
Trichy, Ariyalur and Cuddalore is called as the Rice Granary of Tamil Nadu, due to its immense potential for rice production. Any disturbance in rice production in the $\mathrm{CDZ}$ will adversely affect the foodgrain production of the state of Tamil Nadu. For this reason, modernization of rice production is constantly pursued with fervor by the State Government machinery with the active support of the Tamil Nadu Agricultural University (TNAU).

1. Dean i/c \& Professor (Agrl. Extension), Kumaraguru Institute of Agriculture, Sakthinagar, Nachimuthupuram 638 315, Erode District, Tamil Nadu, 2. Professor (Agrl. Economics), Soil \& Water Management Research Institute, TNAU, Thanjavur, Tamil Nadu and 3. Director i/c, Tamil Nadu Rice Research Institute, TNAU, Aduthurai-612 101, Thanjavur District, Tamil Nadu

Received : 10-11-2017; Accepted : 17-01-2018 
Among the several state government initiatives, during June 2015 the government of Tamil Nadu launched the "Kuruvai Special Assistance 2015 for Delta districts" to boost rice production and productivity. India can occupy 1st position in world rice production, provided appropriate policies and institutional mechanisms are implemented (Vision 2030, CRRI, Cuttack, 2011). One of the main components of this Kuruvai (June to Sep.) special package was the promotion of 'Machine Transplantation' of rice seedlings, for which the State Departments of Agriculture and Agrl. Engineering took substantial efforts for mobilizing machine transplanters. Those farmers who went for Kuruvai rice cultivation were covered under this programme, whose fields were machine transplanted at subsidized rates.

In order to assess the impact of this machine transplantation programme, a study was conducted with the following objectives:

To assess the economics of mechanical transplantation in rice cultivation, especially in terms of productivity and net profit advantages.

Toascertain the feedback offarmers regarding mechanical transplantation in rice cultivation, so as to understand the potential for sustained adoption.

\section{METHODOLOGY}

Ex-postfacto research methodology was followed in order to trace the effects of machine transplantation in rice cultivation. The study was conducted in the six delta districts of Tamil Nadu viz., Thanjavur, Tiruvarur, Nagapattinam, Trichy, Ariyalur and Cuddalore, in which the "Kuruvai Special Assistance 2015 for Delta districts" was implemented by the Government of Tamil Nadu to boost rice production during Kuruvai season in 2015.

In order to select the sample farmers for the study, the list of beneficiaries covered under the "Kuruvai Special Assistance 2015 for Delta districts" was obtained from the Office of the Joint Directors of Agriculture of the respective delta districts. As on 31 July, 2015, a total number of 1,006 farmers were covered under the mechanical transplantation component of the Kuruvai package.

It was decided to select 25 per cent of the population as sample for the study, and accordingly the sample size was fixed as 250, which was selected from the six districts by following proportionate random sampling method. The selected 250 farmers were post-stratified into conventional and machine transplantation farmers. Out of the 250 farmers, 72 of them had followed conventional planting also, and in order to compare the improvement, these farmers were also studied.

The primary data were collected from the sample respondents through two rounds of survey. The first survey was conducted immediately after 
transplanting, during last week of July 2015 and first week of August 2015, and the second survey was conducted after harvest of the crop ie. during third and fourth week of October 2015.

Two well-structured and pre-tested interview schedules were used to collect the primary data during the two rounds of survey. The interview schedules covered different aspects in accordance with the objectives of the study, such as farmers' profile characteristics, economics of conventional and machine planting, yield particulars, net profit, besides feedback of farmers on mechanical transplanting.

The data collected were tabulated in excel sheet. Percentage analysis was carried out for meaningful interpretation of the data generated.

\section{FINDINGS AND DISCUSSION}

\section{Personal Characteristics of the Respondents}

Majority (54.00 \%) of the respondents were in the age group of 30-50 years, followed by 43.60 percent in the age group of more than 50 years. More than three-fourths (78.00\%) of the respondents had secondary, higher secondary or graduate level of education. Farming experience of a majority $(58.00$ $\%)$ of the respondents ranged between 21 to 30 years and above. More than one-third $(36.00 \%)$ of the respondents were large farmers, followed by medium farmers (34.40\%), small farmers (26.65 $\%)$, and the rest $(3.60 \%)$ were marginal farmers. A large proportion (42.00\%) of the respondents were in the income category of less than one lakh rupees per year, followed by the income category of one to two lakh rupees per year (39.60\%).

\section{Comparative Economics of Conventional and Machine Transplanted Rice}

The comparative economics of conventional and machine transplanted rice per acre is given in Table 1 .

\section{Nursery Cost}

In this part of the analysis, three situations of seedling production were considered for computing the economics of nursery cost viz., (i) Conventional method of seedling production for conventional planting (traditional method), (ii) Mat nursery method of seedling production by farmers themselves for mechanical transplanting, and (iii) Direct purchase of seedlings from commercial nurseries for mechanical transplanting.

With regard to use of human labour in conventional nursery, for seven man days employed the cost incurred was Rs.910.00 per acre. Whereas, in the case of mat nursery seedling production, it was just three labour man days at a cost of Rs.580.00. Therefore, the net difference in human labour employed between conventional and mat nursery methods was four man days, which in monetary terms works out to Rs. 330.00 per acre. 
Table 1.

Comparative Economics of Conventional and Machine Transplanted Rice (per acre)

$(\mathrm{n}=250)$

\begin{tabular}{|c|c|c|c|c|c|c|}
\hline \multirow{2}{*}{$\begin{array}{l}\text { S1. } \\
\text { No. }\end{array}$} & \multirow{2}{*}{ Particulars } & \multicolumn{2}{|c|}{ Conventional Nursery } & \multicolumn{2}{|c|}{ Mat Nursery } & \multirow{2}{*}{\begin{tabular}{|c|}
$\begin{array}{c}\text { Purchase } \\
\text { from } \\
\text { Commercial } \\
\text { Nursery }\end{array}$ \\
Cost (Rs.) \\
\end{tabular}} \\
\hline & & $\begin{array}{l}\text { Physical } \\
\text { Quantity }\end{array}$ & Cost (Rs.) & $\begin{array}{l}\text { Physical } \\
\text { Quantity }\end{array}$ & $\begin{array}{l}\text { Cost } \\
\text { (Rs.) }\end{array}$ & \\
\hline \multirow[t]{8}{*}{ I. } & $\begin{array}{l}\text { Nursery Operational } \\
\text { costs }\end{array}$ & & & & & \multirow{7}{*}{$\begin{array}{c}2300 \text { to } \\
2800\end{array}$} \\
\hline & $\begin{array}{l}\text { Human labour (Man } \\
\text { days) }\end{array}$ & 6.40 & 910.00 & 2.60 & 580.00 & \\
\hline & Machine power (Hours) & 1.16 & 604.80 & 0.80 & 320.00 & \\
\hline & Seeds (Kg) & 38.26 & 1247.20 & 19.96 & 624.20 & \\
\hline & $\begin{array}{l}\text { Manures \& Fertilizers } \\
\text { (Kg) - DAP }\end{array}$ & 17.00 & 360.00 & 2.20 & 36.00 & \\
\hline & $\begin{array}{l}\text { Plant protection } \\
\text { chemicals (Ml) }\end{array}$ & 118.00 & 120.00 & 56.00 & 58.00 & \\
\hline & $\begin{array}{l}\text { Interest on working } \\
\text { capital @7\%-12\% }\end{array}$ & -- & 307.99 & -- & 153.73 & \\
\hline & Total cost & & 3549.99 & & \multicolumn{2}{|c|}{$\begin{array}{c}1771.93(1770- \\
2550)\end{array}$} \\
\hline II. & $\begin{array}{l}\text { Main Field } \\
\text { Operational costs }\end{array}$ & & & & & \\
\hline & $\begin{array}{l}\text { Land preparation } \\
\text { (Bund clearing and } \\
\text { cage wheel ploughing) }\end{array}$ & $\begin{array}{c}2 \text { A type } \\
\text { labour }+ \\
1.95 \text { hours } \\
\text { (tractor / } \\
\text { power tiller) }\end{array}$ & 3047.17 & $\begin{array}{c}4 \text { A type } \\
\text { labour }+ \\
2.15 \text { hours } \\
\text { (tractor } \\
\text { / power } \\
\text { tiller) }\end{array}$ & \multicolumn{2}{|c|}{4107.16} \\
\hline & $\begin{array}{l}\text { Pulling of seedlings } \\
\text { and transportation } \\
\text { to main field }\end{array}$ & $\begin{array}{c}5.71 \text { A type } \\
\text { labour }\end{array}$ & 1750.00 & -- & \multicolumn{2}{|r|}{--} \\
\hline & Planting & $\begin{array}{c}15.50 \mathrm{~B} \\
\text { type labour }\end{array}$ & 1536.67 & $\begin{array}{l}3 \text { B type } \\
\text { labour for } \\
\text { gap filling }\end{array}$ & \multicolumn{2}{|c|}{$360.00 *$} \\
\hline & Manures and fertilizers & $160-180 \mathrm{~kg}$ & 3307.50 & $144.83 \mathrm{~kg}$ & \multicolumn{2}{|c|}{$3127.50 * *$} \\
\hline
\end{tabular}




\begin{tabular}{|c|c|c|c|c|c|c|}
\hline \multirow{2}{*}{$\begin{array}{l}\text { S1. } \\
\text { No. }\end{array}$} & \multirow{2}{*}{ Particulars } & \multicolumn{2}{|c|}{ Conventional Nursery } & \multicolumn{2}{|c|}{ Mat Nursery } & \multirow{2}{*}{$\begin{array}{c}\begin{array}{c}\text { Purchase } \\
\text { from }\end{array} \\
\text { Commercial } \\
\text { Nursery }\end{array}$} \\
\hline & & $\begin{array}{l}\text { Physical } \\
\text { Quantity }\end{array}$ & Cost (Rs.) & $\begin{array}{l}\text { Physical } \\
\text { Quantity }\end{array}$ & $\begin{array}{l}\text { Cost } \\
\text { (Rs.) }\end{array}$ & \\
\hline & Plant protection & $480 \mathrm{ml}$ & 1659.83 & $367.33 \mathrm{ml}$ & \multicolumn{2}{|c|}{1163.50} \\
\hline & $\begin{array}{l}\text { Weed management } \\
\text { (Conoweeder as } \\
\text { applied to mechanical } \\
\text { transplanting @ Rs. } \\
\text { 300-400 per labourer } \\
\text { for } 33 \text { cents) }\end{array}$ & $\begin{array}{l}11.83 \\
\text { labour }\end{array}$ & 2148.50 & $\begin{array}{l}9 \text { B type } \\
\text { labour }\end{array}$ & \multicolumn{2}{|c|}{2193.83} \\
\hline & $\begin{array}{l}\text { Harvest (Combined } \\
\text { harvester) }\end{array}$ & 1.30 hours & 2609.00 & 1.27 hours & \multicolumn{2}{|c|}{2593.17} \\
\hline & $\begin{array}{l}\text { Interest on working } \\
\text { capital@ } 9 \%-12 \%\end{array}$ & -- & 1525.57 & -- & \multicolumn{2}{|c|}{1286.79} \\
\hline & $\begin{array}{l}\text { Total Cost (after } \\
\text { planting) }\end{array}$ & -- & 17584.24 & -- & \multicolumn{2}{|c|}{14831.95} \\
\hline \multirow[t]{3}{*}{ III. } & $\begin{array}{l}\text { (Grand) Total } \\
\text { cost of cultivation } \\
\text { (Summation of I \& II) }\end{array}$ & -- & $\begin{array}{l}21134.23 \\
(100.00)\end{array}$ & -- & \multicolumn{2}{|c|}{ (100.00) } \\
\hline & $\begin{array}{l}\text { Productive tillers /sq. } \\
\text { metre }\end{array}$ & \multicolumn{2}{|c|}{334.17} & \multicolumn{3}{|c|}{467.83} \\
\hline & Yield (Kg/acre) & \multicolumn{2}{|c|}{1643.33} & \multicolumn{3}{|c|}{2281.00} \\
\hline
\end{tabular}

*Excluding the subsidy amount of Rs. 2375/- per acre for mechanical transplanter. **xcluding the subsidy amount of Rs. 315/- per acre for micronutrients. *** Excluding the subsidy amount of Rs. 2690/-per acre for mechanical transplanter plus micronutrients.

Similarly, with respect to use of machine power (power tiller) in nursery, the cost incurred was lesser for mat nursery method (preparation of nursery beds) to the tune of Rs. 320.00, when compared to conventional method (Rs. 604.80).

In the case of seed rate, there was significant difference between seed rate followed in conventional method and mat system of seedling production. Under conventional method, the seed rate generally followed per acre is 35 to $55 \mathrm{kgs}$, whereas for mechanical transplanting, the seed rate required per acre is just 20 kgs. Therefore, the net difference in seed rate per acre was 20 to $35 \mathrm{kgs}$, equivalent to Rs. 600 to $1,050.00 /-$

As far as application of fertilizers is concerned, on an average $20 \mathrm{kgs}$ of 
DAP (Diammonium Phosphate) was applied in conventional nursery valued at Rs.360.00; and on the other hand just two kgs was applied in mat nursery method at a cost of Rs.36.00. As a result, there was a saving of Rs.324.00 due to mat nursery method.

In respect of use of plant protection chemicals, on an average 118 $\mathrm{ml}$. of insecticides/fungicides was used in conventional nursery, which costs Rs.120.00. Compared with mat nursery method, the respondent farmers had used only $56 \mathrm{ml}$. of insecticides/fungicides costing Rs.58.00. This has resulted in a saving of Rs.62.00 under mat nursery method.

Further, the total cost of seedling production under conventional method of planting worked out to Rs. 3549.99. In the case of mechanical transplanting, the cost of seedlings worked out to Rs. 1771.93 per acre for mat nursery prepared by the farmers themselves, and Rs. 2300 to 2800.00 per acre for purchase of seedlings from commercial nurseries. Therefore, there was a saving of Rs.1778.06 (50.08 \%) under own mat nursery method, and Rs. 1049.99 with purchase of seedlings (29.57\%).

\section{Main Field Cost}

From Table 1 it is seen that seven major components were considered to work out the cost of rice cultivation in the main field viz., land preparation, seedling pulling and transportation to main field, planting, manures and fertilizers, plant protection, weed management and harvest.

The average expenditure incurred per acre on land preparation under conventional and mechanical transplanting worked out to Rs. 3047.17 and Rs. 4107.16 respectively. Under mechanical transplanting, the expenditure incurred on land preparation was 34.79 per cent higher than that of conventional method, since extra efforts were taken by farmers for land leveling.

Further, farmers who did conventional planting had spent about Rs. 1750.00 per acre towards pulling of seedlings and transportation to main field. This was one of the major cost components under conventional method of rice planting.

With respect to planting, the conventional method required 15.50 women labourers per acre at a cost of Rs. 1536.67 per acre. In the case of mechanical transplanting, gap filling was an additional activity to be undertaken after machine planting by employing about2 to 3 women labourers per acre leading to an additional cost of Rs. 360.00 per acre.

The average cost of manures and fertilizers for conventional and mechanical planted rice crop per acre was Rs. 3307.50 and Rs. 3127.50 respectively.

As far as plant protection was 
concerned, the crop in the main field was found to be uniform and well established under machine planting when compared to conventional method due to optimum population coupled with young seedlings planted at shallow depth. Machine planting with optimum inter and intra row spacing also paved way for better micro-climate with good aeration, which led to less incidence of pest and diseases, and as a result less expenditure was incurred on plant protection (Rs. $1163.50 /$ acre), which is 42.66 per cent less when compared to the conventional method of planting (Rs. 1659.83/-acre).

The study indicates that there was more expenditure on weeding in the case of machine planted fields (Rs. 2193.83 /acre) as compared to manually planted fields (Rs. 2148.50 /acre). The increase in expenditure on weeding under machine planting might be due to excess wages paid for the cono weeder operators ranging from Rs. 300-400 per person per 33 cents per time. But cono weeding is very much essential for better aeration besides facilitating formation of new roots thereby enhanced uptake of nutrients is made possible.

There was no significant difference on expenses incurred on harvesting since all the farmers had used the combined harvester.

The total cost incurred in the main field for conventional planting was Rs.17584.24. At the same time it was 14831.95 in the case of mechanical transplanting, with a saving of Rs.2752.29 (15.65\%) over the conventional planting.

The total cost of cultivation figures indicate that Rs.21134.23 has been incurred for conventional planting, while Rs.16603.88 has been incurred under mechanical transplanting, with a saving of Rs.4530.35 (21.44\%).

\section{Cost and Returns}

The cost and returns with respect to conventional and mechanical planting methods are presented in Table 2.

It is seen that the yield (productivity) increase of more than 38.83 per cent was reported in case of mechanically transplanted fields as compared to manually planted fields. Cost of cultivation was almost 21.44 per cent lesser in the case of mechanically transplanted fields as compared to conventionally transplanted fields because of reduction in cost of seed, manures and fertilizers and plant protection chemicals. The reduction or saving in the cost of cultivation automatically resulted in the fall of cost of production by 43.41 per cent in the case of machine planting as compared to conventional planting. Finally, it is observed that the gross return as well as net return were significantly higher, with 38.83 per cent increase in gross return and almost four times increase in net return (447.54 percent). Almost 40 to 50 per cent increase in number of productive tillers per hill under machine planting 
would have paved way for increase in yield / productivity of the crop, which reflected in increased net income per acre.

Table 2.

Cost and Returns in Rice Cultivation

\begin{tabular}{|c|l|c|c|c|}
\hline $\begin{array}{c}\text { S1. } \\
\text { No. }\end{array}$ & \multicolumn{1}{|c|}{ Particulars } & $\begin{array}{c}\text { Conventional } \\
\text { Planting (Rs.) }\end{array}$ & $\begin{array}{c}\text { Mechanical } \\
\text { Transplanting } \\
\text { (Rs.) }\end{array}$ & Sign \\
\hline 1. & $\begin{array}{l}\text { Yield (productivity) in quintals } \\
\text { per acre }\end{array}$ & 16.43 & 22.81 & More (+) \\
\hline 2. & $\begin{array}{l}\text { Average price received (per } \\
\text { quintal) }\end{array}$ & 1476.00 & 1476.00 & Nil \\
\hline 3. & Cost of cultivation (Rs. per acre) & 21134.23 & $16603.88^{*}$ & Less $(-)$ \\
\hline 4. & $\begin{array}{l}\text { Cost of production (Rs. per } \\
\text { quintal) }\end{array}$ & 1286.32 & $727.92^{*}$ & Less $(-)$ \\
\hline 5. & Gross return (per acre) & 24250.68 & 33667.56 & More $\left(^{+}\right)$ \\
\hline 6. & Net return (per acre) & 3116.45 & 17063.68 & More $(+)$ \\
\hline
\end{tabular}

*Excluding the subsidy amount of Rs. 2690/-per acre (Rs. 2365/-plus Rs. 315/-) for mechanical transplanter plus micronutrients.

\section{Farmers' feedback}

Farmers' feedback regarding mechanical transplantation in rice cultivation was elicited so as to understand the potential for sustained adoption. The analysis of farmers' feedback is presented in Tables 3-7.

\section{Reasons for Adoption of Mechanical Transplantation}

The reasons for adoption of mechanical planting method were analysed and the results are presented in Table 3.
From Table 3, it is seen that 100 per cent of the respondents had reported that 'to overcome labour scarcity during planting season', and 'significant yield increase' as the major reasons for adoption of machine planting arranged by the government. This was followed by 'to maintain perfect spacing between plants and rows which ensured optimum population'(as per recommendation), which resulted in good aeration and less pest and disease incidence (there was no report of blast disease in machine transplanted fields, whereas blast occurrence was reported in conventionally planted fields). 
Table 3.

Distribution of Respondents according to Reasons for Adoption of Mechanical Transplantation

\begin{tabular}{|l|l|c|c|c|}
\hline $\begin{array}{c}\text { S1. } \\
\text { No. }\end{array}$ & \multicolumn{1}{|c|}{ Particulars } & $\begin{array}{c}\text { No. of } \\
\text { Respondents }\end{array}$ & Percentage & Rank \\
\hline 1. & $\begin{array}{l}\text { To overcome labour scarcity during } \\
\text { planting season }\end{array}$ & 250 & 100.00 & I \\
\hline 2. & Significant yield increase & 250 & 100.00 & II \\
\hline 3. & $\begin{array}{l}\text { To maintain perfect spacing(optimum } \\
\text { plant population) }\end{array}$ & 196 & 78.40 & III \\
\hline
\end{tabular}

\section{Level of Satisfaction on Mechanical Transplanting}

The level of satisfaction on mechanical transplanting as reported by the respondents were analysed and the results are presented in Table 4.

It is inferred from Table 4 that nearly two-thirds $(64.80 \%)$ of the respondents had reported that they were 100 per cent satisfied with the machine transplantation programme of the state government. This was followed by
33.20 per cent of the respondents who expressed that their level of satisfaction was 51 to 75 per cent due to the reasons that: it may not be a suitable method of planting during rainy season as the field requires extra care for the first 20 days after mechanical transplantation in terms of providing proper drainage facility, and irrigation should be given as and when disappearance of water from the field. The rest $(2.00 \%)$ of the respondents were only satisfied up to the level of 26 to 50 per cent, since they felt

Table 4.

Distribution of Respondents according to Level of Satisfaction on Mechanical Transplantation Programme

\begin{tabular}{|c|c|c|c|c|c|c|}
\hline \multirow{2}{*}{$\begin{array}{l}\text { S1. } \\
\text { No. }\end{array}$} & \multirow{2}{*}{ District } & \multicolumn{5}{|c|}{ Level of Satisfaction } \\
\hline & & $0-25 \%$ & $26-50 \%$ & $51-75 \%$ & $76-100 \%$ & Total \\
\hline 1. & Thanjavur & -- & 03 & 21 & 04 & $28(11.20)$ \\
\hline 2. & Tiruvarur & -- & -- & 27 & 103 & $130(52.00)$ \\
\hline 3. & Nagapattinam & -- & -- & 22 & 23 & $45(18.00)$ \\
\hline 4. & Cuddalore & -- & -- & 04 & 21 & $25(10.00)$ \\
\hline 5. & Ariyalur & -- & 02 & 07 & 03 & $12 \quad(4.80)$ \\
\hline 6. & Trichy & -- & -- & 02 & 08 & $10 \quad(4.00)$ \\
\hline \multicolumn{2}{|c|}{$\begin{array}{l}\text { Overall Cauvery } \\
\text { Delta }\end{array}$} & - & $\begin{array}{c}05 \\
(2.00)\end{array}$ & $\begin{array}{c}83 \\
(33.20)\end{array}$ & $\begin{array}{c}162 \\
(64.80)\end{array}$ & $\begin{array}{c}250 \\
(100)\end{array}$ \\
\hline
\end{tabular}


that their fields were clayey in nature and machine planting the seedlings too deep in the soil caused delay in establishment of seedlings during the initial period, moreover providing proper drainage in clay soil also becomes difficult.

\section{Merits of Machine Transplanting}

The findings on the merits of machine transplanting are given in Table 5 .

From Table 5, it is seen that 100 percent of the beneficiaries have

Table 5.

\section{Distribution of Respondents according to Merits of Mechanical Transplanting}

\begin{tabular}{|c|l|l|l|}
\hline $\begin{array}{c}\text { S1. } \\
\text { No. }\end{array}$ & \multicolumn{1}{|c|}{ Merits } & \multicolumn{1}{|c|}{$\begin{array}{c}\text { No. of } \\
\text { Respondents }\end{array}$} & Percentage \\
\hline 1. & $\begin{array}{l}\text { Mental agony of rice cultivation reduced } \\
\text { significantly }\end{array}$ & 250 & 100.00 \\
\hline 2. & Increase in number of productive tillers & 250 & 100.00 \\
\hline 3. & $\begin{array}{l}\text { Reduction in seed rate resulted in decreased } \\
\text { cultivation cost }\end{array}$ & 250 & 100.00 \\
\hline 4. & Reduction in time period of planting & 214 & 85.60 \\
\hline 5. & Timely planting made possible & 196 & 78.40 \\
\hline 6. & Possible to plant young seedlings & 179 & 71.60 \\
\hline 7. & Labour scarcity addressed & 107 & 42.80 \\
\hline 8. & Nursery management significantly reduced & 45 & 18.00 \\
\hline
\end{tabular}

reported that 'mental agony of rice cultivation reduced significantly', 'increase in number of productive tillers', and 'reduction in seed rate resulted in decreased cultivation cost' as the major merits in machine transplanting.

\section{Demerits of Machine Transplanting}

The findings on the demerits of machine transplanting are given in Table 6 . It is seen from Table 6 that cent percent of the respondents reported that 'skill involved in nursery preparation', and 'more care should be given after planting in main field' as the two major demerits in mechanical transplanting.

\section{Suggestions for improvement of the Programme}

The analysis of the suggestions for improvement of the programme is presented in Table 7.

From Table 7 it is seen that two suggestions viz., 'subsidy may be extended 
for few more years to increase adoption rates' $(42.80 \%)$ and 'Cono weeder and laser leveler may be made available at Agri. depots and PACS' $(35.60 \%)$ were offered by the respondents for further improvement of the programme.

Majority of the respondents had realized the importance of land leveling

Table 6.

Distribution of Respondents according to Demerits of Mechanical Transplanting

\begin{tabular}{|c|c|c|c|}
\hline S1. No. & Demerits & $\begin{array}{c}\text { No. of } \\
\text { Respondents }\end{array}$ & Percentage \\
\hline 1. & Skill involved in nursery preparation & 250 & 100.00 \\
\hline 2. & $\begin{array}{l}\text { More care should be given after planting } \\
\text { in main field (minimum } 15 \text { days extra } \\
\text { care should be taken) }\end{array}$ & 250 & 100.00 \\
\hline 3. & $\begin{array}{l}\text { Cost of gap filling as additional expense } \\
\text { to be incurred by farmer }\end{array}$ & 205 & 82.00 \\
\hline 4. & $\begin{array}{l}\text { Not suitable for rainy (wet) season } \\
\text { (Thaladi season) }\end{array}$ & 179 & 71.60 \\
\hline 5. & $\begin{array}{l}\text { Not suitable for (fluffy soils) with highly } \\
\text { clayey content }\end{array}$ & 116 & 46.40 \\
\hline 6. & $\begin{array}{l}\text { Non availability of cono weeder / power } \\
\text { weeder }\end{array}$ & 107 & 42.80 \\
\hline 7. & $\begin{array}{l}\text { Lack of expertise in mat / tray (cake) } \\
\text { nursery making }\end{array}$ & 89 & 35.60 \\
\hline 8. & Proper drainage facility required & 89 & 35.60 \\
\hline 9. & $\begin{array}{l}\text { Proper land leveling necessary before } \\
\text { transplanting }\end{array}$ & 89 & 35.60 \\
\hline 10. & $\begin{array}{l}\text { Uneven planting in fluffy soils with } \\
\text { highly clayey content }\end{array}$ & 27 & 10.80 \\
\hline 11. & $\begin{array}{l}\text { Difficulty in mobility of transplanter } \\
\text { between fields (in small fields) and low } \\
\text { lying lands }\end{array}$ & 27 & 10.80 \\
\hline
\end{tabular}


Table 7.

Distribution of Respondents according to Suggestions for improvement of the Programme

\begin{tabular}{|l|l|c|c|}
\hline $\begin{array}{c}\text { S1. } \\
\text { No. }\end{array}$ & $\begin{array}{l}\text { Suggestions } \\
\text { No. of } \\
\text { Respondents }\end{array}$ & Percentage \\
\hline 1. & $\begin{array}{l}\text { Subsidy may be extended for few } \\
\text { more years to increase adoption rates }\end{array}$ & 107 & 42.80 \\
\hline 2. & $\begin{array}{l}\text { Cono weeder and laser leveler may } \\
\text { be made available at Agri depots } \\
\text { and PACS (Primary Agricultural } \\
\text { Cooperative Societies) }\end{array}$ & 89 & 35.60 \\
\hline
\end{tabular}

as a pre-requisite for machine planting. As a result, farmers have insisted government support in terms of monetary or subsidized custom hiring facilities in all revenue villages. Farmers have felt that Cono weeding under machine planted field improves the crop growth and productivity and hence, they have demanded supply of adequate number of Cono weeders through Government Depots under any subsidy scheme. It was also learnt that farmers need to be given hands-on training on mat nursery technology in their villages.

\section{CONCLUSION}

The study revealed that nearly two-thirds $(64.80 \%)$ of the respondents were 100 per cent satisfied with the machine transplantation programme, followed by about one-third (33.20\%) of the respondents who had expressed 51-75 per cent level of satisfaction.
This clearly indicates the reasonable success of the initiative of the Tamil Nadu Government in ushering in the use of mechanical transplanter for rice cultivation in the state in large scale, which has resulted in increasing the efficiency of farm operations and solved the labour scarcity problem facing rice cultivation. Farmers have demanded that 'subsidy may be extended for few more years to increase adoption rates', which was fulfilled adequately, as in the year 2016 and 2017 the subsidy package was again implemented in the delta districts. Farmers have also expressed that 'skill involved in nursery preparation', and 'extra care should be given after planting in main field' as their major concerns in following mechanical transplanting, which needs to be addressed by the State Department of Agriculture for sustained adoption of the mechanical transplanter. 


\section{REFERENCES}

Rajeshkanna, K., Theodore, R.K \& Sivakumar, S.D (2005). Evaluation of Market-Led-Horticulture under the Tamil Nadu Precision Farming Project, Journal of Extension Education, 17 (3\&4): 3785-3791.
Veerendranath.G \& Shailaja, A . (2009). Impact of Watershed Development Programme in Mahaboobnagar District of Andhra Pradesh, Journal of Extension Education, 21 (2): 4197-4203. 